\title{
Immunoregulatory T-lymphocyte subset deficiency in newly diagnosed Type 1 (insulin-dependent) diabetes mellitus
}

\author{
A. Galluzzo, C. Giordano, G. Rubino and G. D. Bompiani \\ Clinica Medica III, University of Palermo, Palermo, Italy
}

\begin{abstract}
Summary. Humoral and cell-mediated disorders in Type 1 (insulin-dependent) diabetes suggest that an imbalance of immunoregulatory T-cell subsets exists. In 23 newly diagnosed (onset $<3$ months) and 21 long-standing Type 1 diabetic patients, $\mathrm{T}$ lymphocyte subsets were analyzed using monoclonal antibodies (OKT3, OKT4, OKT8, OKM1). The newly diagnosed patients showed a reduction with a significant difference from healthy controls in total $\mathrm{T}$ cells $\left(\mathrm{OKT}^{+}: 58.1 \pm\right.$ $8.5 \%$ versus $70.7 \pm 8.0 \%$ ), helper/inducer cells $\left(\mathrm{OKT}^{+}\right.$: $33.8 \pm 7.0 \%$ versus $47.1 \pm 8.3 \%$ ), suppressor/cytotoxic cells $\left(\mathrm{OKT}^{+}: 18.5 \pm 7.3 \%\right.$ versus $\left.32 \pm 6.8 \%\right)$ and monocytes $\left(\mathrm{OKM}^{+}:\right.$: $11.5 \pm 3.8 \%$ versus $\left.19.9 \pm 5.2 \%\right)(p<0.001)$. The long-standing diabetic patients also revealed a low number of immunoregulatory $\mathrm{T}$ cells compared with control subjects, although to a lesser extent $(p<0.01-0.05)$. The helper/suppressor ratio $\left(\mathrm{OKT}_{4}+/ \mathrm{OKT}^{+}\right)$was higher in newly diagnosed
\end{abstract}

patients than in control subjects $(2.2 \pm 1.3$ versus $1.5 \pm 0.3$; $p<0.02$ ). When compared with $95 \%$ tolerance limits in the control subjects, the reduction of OKT $8{ }^{+}$cells in the newly diagnosed diabetic patients appeared more marked: the mean (18.5\%) coincided with the lower limit of normal subjects (18.3\%). Ten of the newly diagnosed Type 1 diabetic patients had a value below the normal lower limit. Our data point to the occurrence of different immunoregulatory abnormalities in newly diagnosed Type 1 diabetic patients, especially in $\mathrm{OKT}^{+}$and $\mathrm{OKT}_{4}{ }^{+}$cells. The imbalance in $\mathrm{T}$ lymphocyte subsets is further proof of the role of cellular autoimmunity in the pathogenesis of the early phases of Type 1 diabetes.

Key words: Type 1 diabetes, suppressor cells, monoclonal antibodies, T-lymphocyte subsets, cell-mediated immunity disorders.
It is well known that disorders of cell-mediated immunity are involved in Type 1 (insulin-dependent) diabetes. These abnormalities comprise hypersensitive reactions, which appear as leucocyte sensitization against pancreas extracts and insulin, decreased lymphocyte blastogenesis with mitogens and antigens and raised $\mathrm{K}$ cell activity [1]. In addition, at the onset of Type 1 diabetes, a deficit of suppressor cell activity has been demonstrated using one-way mixed lymphocyte culture and concanavalin A-induced suppressor cells [1-3].

It is commonly accepted that immune homeostasis is maintained through a tightly controlled balance between inducer and suppressor T-cell subsets [4]. In man, $\mathrm{T} 4$ and $\mathrm{T} 8$ antigens are expressed on helper/inducer and suppressor/cytotoxic lymphocyte subsets, respectively. T4 positive $T$ cells possess helper function for the development of both cell-mediated immune responses and B-cell immunoglobulin production and secretion [4-7]. On the above basis, it is reasonable to hypothesize that an imbalance in these lymphocyte subpopulations exists in Type 1 diabetes. This possible immunoregula- tory T-cell defect in genetically susceptible subjects (linked with HLA diabetogenic haplotype) may generate the autoaggression against pancreatic $\beta$ cells through activation of humoral and cell-mediated mechanisms [8-9]. With a view to confirming this hypothesis, we studied T-lymphocyte phenotypes in newly diagnosed and long-standing Type 1 diabetic patients. Tlymphocyte subsets have been defined by monoclonal antibodies which identify total $\mathrm{T}$ cells $\left(\mathrm{OKT} 3^{+}\right)$, helper/inducer cells $\left(\mathrm{OKT}_{4}^{+}\right)$, suppressor/cytotoxic cells $\left(\mathrm{OKT}^{+}\right)$and monocytes $\left(\mathrm{OKM} 1^{+}\right)$.

\section{Subjects and methods}

\footnotetext{
Subjects

Twenty-three patients ( 10 males and 13 females) with newly diagnosed Type 1 diabetes were studied. Their mean age was $15 \pm 4.7$ years (range: 6-24 years). At the time of our study the time from onset of the disease was $<3$ months, the diagnosis time being established on the basis of anamnesis concerning the beginning of symptoms. Twenty-
} 
one long-standing Type 1 diabetic patients (12 males and 9 females; mean age $17.6 \pm 3.1$ years; range: $10-28$ years) were studied also; their mean duration of diabetes was $4.5 \pm 3.2$ years (range: $1-10$ years).

All patients in both groups were ketosis-prone and had required insulin from the time of diagnosis. At the time of our study they all had good metabolic control: no or minimal glycosuria, as measured with Clinistix (Miles Ames, Elkhart, Indiana, USA), absence of ketonuria as measured with Ketostix (Miles Ames) and satisfactory 24-h glycaemic profiles, as evaluated with reactive strips (Dextrostix) read with a reflectance meter (Dextrometer, Miles Ames) [10].

Twenty-one healthy subjects ( 11 males and 10 females, children, students, volunteers and laboratory staff, with no family history of diabetes), ranging in age from 10 to 30 years (mean age $16.3 \pm$ 6.1 years) were investigated also.

\section{Isolation and identification of Tlymphocyte subsets}

Human peripheral blood mononuclear cells were prepared by FicollHypaque density centrifugation [11]. Cell counts revealed preparations containing $>88 \%$ small lymphocytes, $2 \%-4 \%$ large lymphocytes, $6 \%-8 \%$ monocytes and $1 \%-2 \%$ neutrophils. Cells reactive with monoclonal antibodies were enumerated by complement-mediated lysis [12] as follows: OKT3, OKT4, OKT8, OKM1 (1 $\mu 1)$ (OrthoMune, Ortho Pharmaceuticals, Raritan, New Jersey, USA) were added individually to $20 \mu \mathrm{l}$ of mononuclear cells $\left(2 \times 10^{6}\right.$ cells $\left./ \mathrm{mm}^{3}\right)$ in RMPI 1640 (Flow Laboratories, Irvine, Scotland, UK) at $4{ }^{\circ} \mathrm{C}$ and incubated for $30 \mathrm{~min}$. Fresh rabbit complement (10 $\mu 1$; Behringwerke, Marburg, FRG) was added and the cells were incubated further at $37^{\circ} \mathrm{C}$ for $1 \mathrm{~h}$. All reactions were performed in triplicate. Viable cells ( 200 cells for each sample with each monoclonal antibody) were enumerated by Trypan-blue exclusion and all samples were adjusted for background lysis of complement-treated control cells. The results were evaluated by two independent observers using a Leitz phase contrast microscope (Leitz Orthoplan, Wetzlar, FRG). Suspensions with $>10 \%$ non-viable cells were discarded. Intra-assay variability was $<5 \%$; inter-assay variability was $<10 \%$. The reagents used (monoclonal antibodies, rabbit complement, tissue culture medium) were from the same batches throughout the study. OKT3 ${ }^{+}$cells were expressed as a percentage of total lymphocytes. OKT4 ${ }^{+}$and OKT $8^{+}$ cells were similarly enumerated and the results expressed as a percentage of $\mathrm{OKT}^{+}$cells. $\mathrm{OKM} 1^{+}$cells were evaluated as a percentage of total lymphocytes. The ratio $\mathrm{OKT} 4^{+} / \mathrm{OKT} 8^{+}$cells was calculated and considered as the immunoregulatory ratio.

\section{Statistical analysis}

All data are expressed as mean $\pm \mathrm{SD}$ and $p$ values were determined using the Student's unpaired t-test, unless otherwise stated. The $95 \%$ tolerance limit in normal control subjects was calculated using Bowker's method [13].

\section{Results}

The mean percentages of $T$ cells and $T$-cell subsets in healthy control subjects were $70.7 \pm 8.0 \%$ (range $52.7-78.7 \%$ ) for OKT3 $^{+}$cells; $47.1 \pm 8.3 \%$ (range $38.8-55.5 \%$ ) for $\mathrm{OKT}_{4}^{+}$cells; $32.0 \pm 6.8 \%$ (range $25.1-38.8 \%$ ) for $\mathrm{OKT}^{+}$cells; $19.9 \pm 5.2 \%$ (range 14.7-25.1\%) for OKM1 ${ }^{+}$cells; $1.5 \pm 0.3$ (range 1.2-1.8) for OKT4/OKT8 ratio. No significant differences were found between healthy males and females with regard to T-cell subsets.

The individual percentages for $\mathrm{OKT}^{+}$and $\mathrm{OKM} 1^{+}$cells in the three groups of subjects are shown in Figure 1 . For OKT3 ${ }^{+}$cells, the newly diagnosed pat-

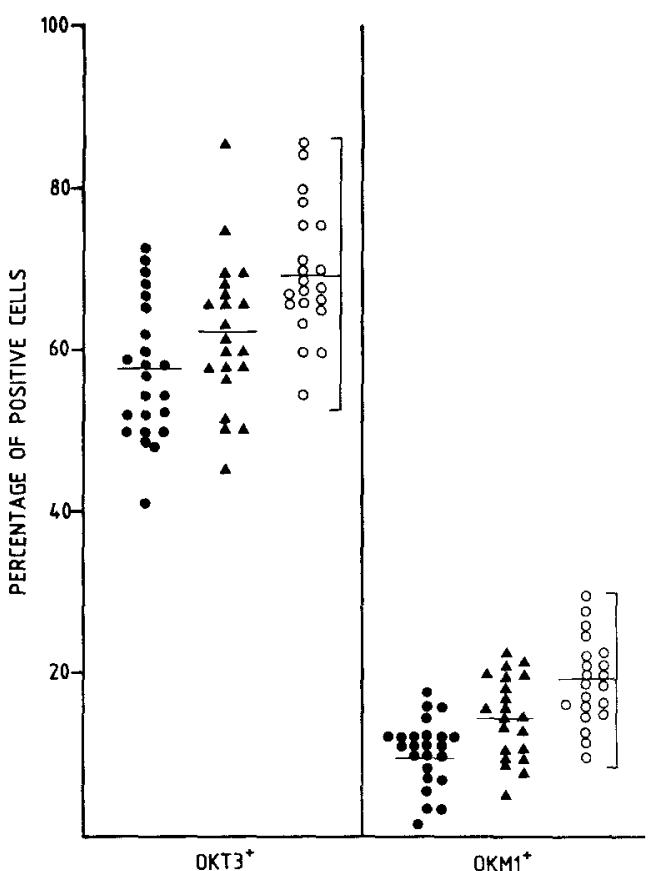

Fig. 1. $\mathrm{OKT}^{+}$and $\mathrm{OKM} 1^{+}$cell percentages in 23 newly diagnosed (-) and 21 long-standing ( $\Delta$ ) Type 1 diabetic patients, and in 21 control subjects $(0)$. The mean $\pm 2 \mathrm{SD}(95 \%$ tolerance limit) for the control subjects is indicated $\left(\mathrm{OKT}^{+}: 70.7 \pm 16.0 \%\right.$; ${ }^{\circ K M} 1^{+}: 19.9 \pm$ $10.4 \%)$

ients showed a reduction $(58.1 \pm 8.5 \%)$ compared with both long-standing patients $(63.5 \pm 8.8 \%)$ and control subjects $(70.7 \pm 8.0 \% ; p<0.05$ and $p<0.001$, respectively). Furthermore, in nine patients the percentage values were below the lower $95 \%$ tolerance limit of controls. Only four long-standing Type 1 diabetic patients had this deficiency. The same phenomenon was observed with monocytes identified by OKM1 antibody: in the two groups of the Type 1 diabetic patients, a reduction was found compared with the normal limit of control subjects. The mean percentage of OKM1 ${ }^{+}$in the newly diagnosed patients $(11.5 \pm 3.8 \%)$ was significantly different from that in control subjects $(19.9 \pm 5.2 \% ; p<$ $0.001)$ and long-standing patients $(15.9 \pm 5.3 \% ; p<$ $0.01)$. The percentages for $\mathrm{OKT}^{+}$and $\mathrm{OKT}^{+}$cells in the two groups are illustrated in Figure 2. The mean value for $\mathrm{OKT}^{+}$cells $(33.8 \pm 7.0 \%)$ in the newly diagnosed patients was near the bottom of the normal tolerance limit (30.4\%) and five of these patients, together with three long-standing diabetic patients had values below this limit. The mean value for $\mathrm{OKT}_{4}{ }^{+}$cells in the remaining long-standing Type 1 diabetic patients $(39.1 \pm 8.9 \%)$ was within the $95 \%$ tolerance limit of the control subjects. There was a significant difference also between the 'newly diagnosed diabetic' OKT4 ${ }^{+}$mean percentages and the control values $(p<0.001)$. For $\mathrm{OKT}^{+}$cells, a significant difference was found in the newly diagnosed patients $(18.5 \pm 7.3 \%)$ compared with the control subjects $(32.0 \pm 6.8 \% ; p<0.001)$. As far as the $\mathrm{OKT} 8^{+}$cell percentages are concerned, this reduction was more marked. Indeed, 10 newly diagnosed 


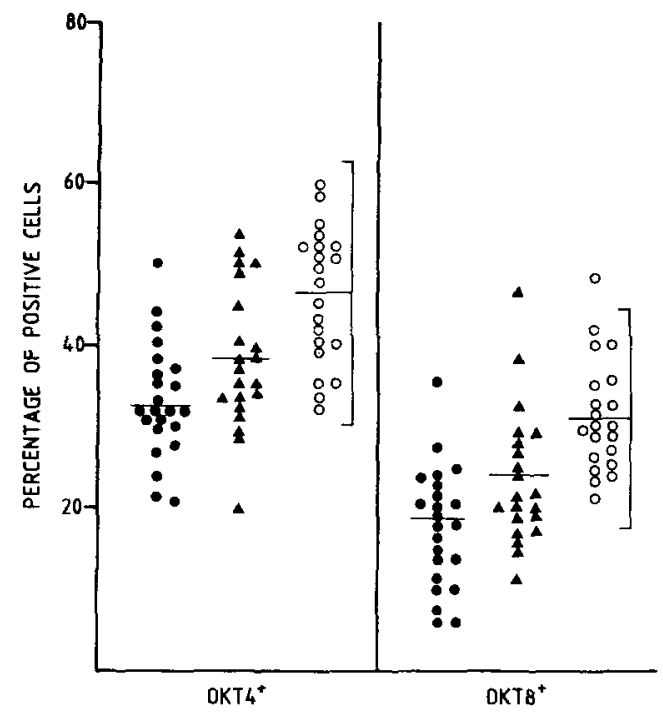

Fig. 2. $\mathrm{OKT}^{+}{ }^{+}$and $\mathrm{OKT} 8^{+}$cell percentages in 23 newly diagnosed (O) and 21 long-standing ( $\Delta$ ) Type 1 diabetic patients, and in 21 control subjects $(O)$. The mean \pm 2 SD $(95 \%$ tolerance limit) for the control subjects is indicated $\left(\mathrm{OKT}_{4}^{+}: 47.1 \pm 16.6 \%\right.$; $\mathrm{OKT}^{+}: 32.0 \pm$ $13.6 \%)$

Type 1 diabetic patients had a value below the normal lower limit (18.3\%) and the mean coincided almost with the bottom of the $95 \%$ tolerance limit of control subjects. The long-standing patients also revealed this reduction, but to a lesser degree.

As regards OKT4/OKT8 ratios, in the newly diagnosed patients the mean was higher $(2.2 \pm 1.3)$ than in control subjects $(1.5 \pm 0.3 ; p<0.02)$. This statistical analysis was performed with the Welch-Aspin solution for the Behrens-Fisher problem [14]. This test, which is a simple modification of the Student's t-test, was used because in the three groups of subjects the variances were significantly different. The results clearly show that the only significant differences lie between the newly diagnosed patients and control subjects. The $\mathrm{OKT}_{4}{ }^{+} / \mathrm{OKT}^{+}{ }^{+}$ratio for the three groups is shown in Figure 3 . The increased mean value $(2.2 \pm 1.3)$ found in the newly diagnosed Type 1 diabetic patients was near to the normal upper limit, but this was due to a very high value observed in one patient (6.1). Another seven patients also showed higher values than the normal upper limit, but the majority (15) of the newly diagnosed Type 1 diabetic patients had normal $\mathrm{OKT}_{4}{ }^{+} / \mathrm{OKT}^{+}$ ratios. Only four long-standing patients showed increased immunoregulatory ratios.

If $\mathrm{OKT}^{+}$cells represent the total populations of $\mathrm{OKT}_{4}{ }^{+}$and $\mathrm{OKT} 8^{+}$cells, the sum of the percentages should equal the percentage of OKT3 ${ }^{+}$cells. But this is not the case; in fact, in the control subjects this sum was greater than the value of $\mathrm{OKT}^{+}$cells. On this basis, it has been supposed by ourselves and others [15] that there is an overlap between the OKT4 and OKT8 subsets, which bear the same receptor antigens. We calculated the percentage of overlap in the three groups, re-

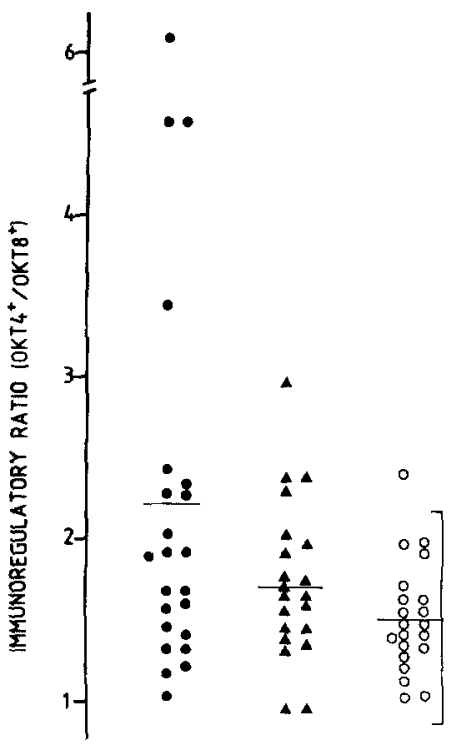

Fig. 3. Ratio of immunoregulatory T-cell subsets $\left(\mathrm{OKT} 4^{+} / \mathrm{OKT}^{+}\right)$ in 23 newly diagnosed ( $)$ and 21 long-standing ( $)$ Type 1 diabetic patients, and in 21 control subjects $(O)$. The mean $\pm 2 \mathrm{SD}(95 \%$ tolerance limit) for the control subjects is indicated $(1.5 \pm 0.6)$

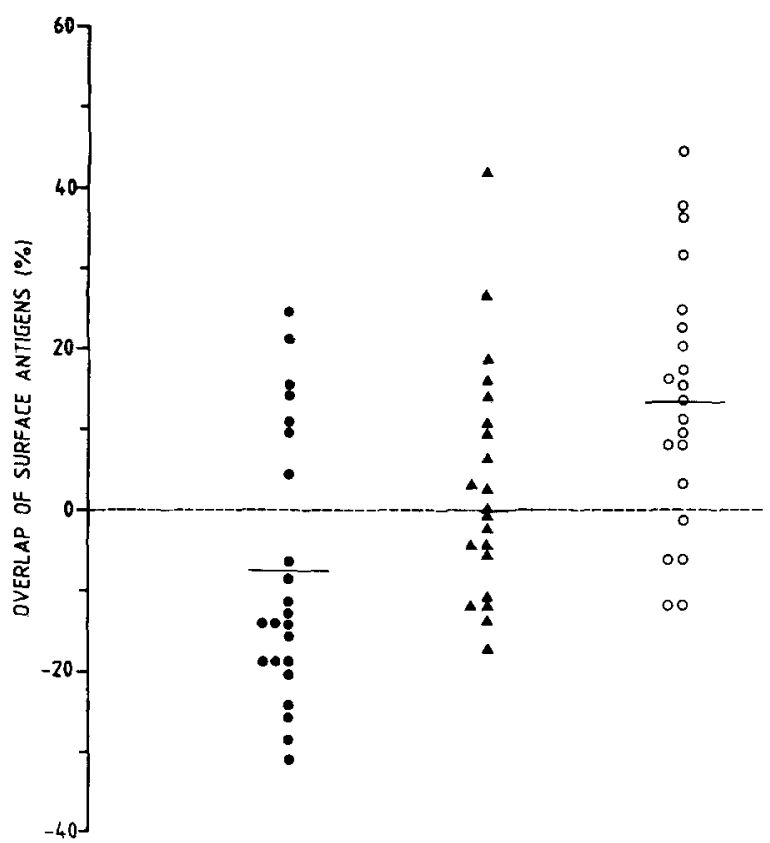

Fig.4. Percentage of overlap of $\mathrm{OKT}_{3}{ }^{+}, \mathrm{OKT}_{4}{ }^{+}$and $\mathrm{OKT}^{+}$surface antigens in newly diagnosed $(\boldsymbol{O})$ and long-standing $(\boldsymbol{\Lambda})$ Type $1 \mathrm{dia}-$ betic and control subjects $(O)$. Bars denote respective mean values

garding it as the sum of $\mathrm{OKT}_{4}^{+}$plus $\mathrm{OKT}^{+}$minus $\mathrm{OKT}^{+}$divided by $\mathrm{OKT}^{+}$cells. The plotted data are shown in Figure 4. The majority of control subjects showed some overlap, but in the newly diagnosed Type 1 diabetic patients, the majority (16 out of 23 ) revealed negative percentages of overlap (range -32 to -0.08 ). This phenomenon, although less pronounced, was present also in the long-standing Type 1 diabetic patients, where 11 out of 21 showed a negative percent- 
age of overlap, while 10 had an overlap ranging from $2 \%$ to $40 \%$. A significant difference was found in the overlap percentages between the newly diagnosed Type 1 diabetic patients and the control subjects $(p<$ 0.001 ). A less significant difference existed between the long-standing patients and normal subjects $(p<0.05)$, while there was no difference between the two groups of diabetic patients.

\section{Discussion}

This report describes a study on immunoregulatory $\mathrm{T}$ cell subsets in Type 1 diabetes. Using monoclonal antibodies, we found that T-lymphocyte phenotypes are decreased in Type 1 diabetic patients, the deficit being particularly significant in newly diagnosed Type 1 diabetic patients.

Many investigators have suggested that cell-mediated immune disorders may be linked to metabolic alterations influencing peripheral blood cells [16]. It must be stressed, however, that our patients were studied when they had satisfactory metabolic control, and the abnormalities were more pronounced in newly diagnosed patients, rather than in long-standing ones, although both groups of patients were analyzed under the same metabolic control conditions. In our opinion the hypothesis that the abnormalities of T-lymphocyte subpopulations in Type 1 diabetes are due to metabolic disturbances can be discounted.

Several studies on T-lymphocyte subsets in Type 1 diabetes have reported conflicting results [17-19]. The discrepancies could be explained by the use of different methods and different monoclonal antibodies. In addition, it is difficult to compare the results with one another because the analyses of $\mathrm{T}$ lymphocytes were performed at different times from onset of disease (range 15 days to 6 months) and in some studies the number of patients was too small. The interval time from diagnosis is very relevant for studies on the immune phenomena in Type 1 diabetes and for this reason we examined Tlymphocyte phenotypes in two groups of diabetic patients: (1) in newly diagnosed patients within 3 months from the onset of the disease (a period in which disorders in immune surveillance mechanisms are very pronounced, as evidenced by the presence of islet cell antibodies, islet cell surface antibodies and by the histological picture of insulitis) $[1,20]$; (2) in long-standing diabetic patients in which, on the contrary, the immunological alterations should be less pronounced or completely absent $[1,19]$. Moreover, it must be stressed that in our study, unlike other investigations, we employed a complement-mediated cytotoxicity technique. The use of this method may account for the high value of overlap phenomenon in the control subjects. However, it is to be emphasized that the overlap has been reported also in healthy subjects using immunofluorescence analysis [15]. On the basis of these considerations, we feel that the reduction of T4, T8, T3 and M1 antigen expression on Type 1 diabetic lymphocytes cannot be related to artefacts of this method, but represent a real characteristic of lymphocyte subpopulations in Type 1 diabetes.

In our study we emphasize the use of $\mathrm{OKT}^{+} /$ $\mathrm{OKT}^{+}$ratios because this affords an index of the imbalance between the subsets. In the newly diagnosed patients the immunoregulatory ratio was higher than 2; however, this rise in the index is due to the low number of diabetic patients with simultaneous increase in $\mathrm{OKT}_{4}{ }^{+}$and decrease in $\mathrm{OKT} 8{ }^{+}$cells. Even though the majority of the newly diagnosed patients shows a normal $\mathrm{OKT}_{4}{ }^{+} / \mathrm{OKT}^{+}{ }^{+}$ratio, it is necessary to consider that this apparently normal value is due to the simultaneous reduction in $\mathrm{OKT}_{4}^{+}$and $\mathrm{OKT} 8^{+}$lymphocytes. The four patients with markedly high values of the $\mathrm{OKT}_{4}^{+} / \mathrm{OKT}^{+}$ratio are just those who have a more pronounced reduction in $\mathrm{OKT} 8^{+}$cells. These patients may represent a particular subgroup within Type 1 diabetes, but they did not show any particular difference in comparison to other patients with respect to severity of the clinical picture or viral infection. The new finding emerging from our study concerns the phenomenon of overlap, absent in the majority of newly diagnosed patients (it was present in seven only). This observation suggests that in newly diagnosed Type 1 diabetic patients there is a numerical reduction of cells bearing both antigens for OKT4 and OKT8 monoclonal antibodies. This reduction, a further indication of subset deficit, may be due to the modified antigens expressed on lymphocyte subpopulations, for example because of an increased number of cells bearing Ia antigens, as recently demonstrated by Jackson et al. [18]. The increase in Iapositive cells may be due to the immune surveillance disequilibrium, especially on account of suppressor cell deficiency. How are we to explain the numerical T lymphocyte deficit in the newly diagnosed Type 1 diabetic patients and, in particular, the reduction in $\mathrm{OKT}_{4}{ }^{+}$and $\mathrm{OKT}^{+}$cells? The typical histological pancreatic picture of Type 1 diabetes is well-known [20], hence our data on numerical $T$-cell decrease might be due to the trapping of $T$ lymphocytes inside the endocrine pancreas. This hypothesis is supported by the similar histological events in Hashimoto's thyroiditis, a disease characterized by $T$ suppressor deficit [21], and by a recent report that in acute-onset Type 1 diabetes labelled $T$ lymphocytes preferentially migrate to the endocrine pancreas [22].

$\mathrm{OKT}^{+}$T-cell deficit may suggest disordered immunoregulation and especially an immune-surveillance defect against pancreatic antigens. OKT4 ${ }^{+}$cell reduction may be explained by the activation of cell cooperation in the target organ. In all events, at the present time no clear-cut interpretation exists. It is likely that immune-regulatory cell reduction in Type 1 diabetes is closely linked to the genetic profile and in particular to HLA-DR3 and/or DR4 haplotypes. In genetically sus- 
ceptible subjects (carriers of HLA-B8, B15, B18 and HLA-DR3 and/or DR4 antigens) the direct or indirect modification of pancreatic $\beta$-cell self-constituents in conjunction with the coincident presence of an inherited defect in immunological control by suppressor $\mathrm{T}$ cells may initiate the autoaggressive pancreatic process. In fact, antigen- or organ-specific $\mathrm{T}$ lymphocytes may fail to control either the intervention of cytotoxic T lymphocytes or the cloning of helper/inducer and consequently $\beta$-cell proliferation and organ-specific antibody production [1]. Recently, this immunological predisposition was suggested also by Gorsuch et al. [23], who demonstrated in the Barts-Windsor Family study that there exists a long prodromal period preceding the onset of Type 1 diabetes.

In conclusion, nowadays it is commonly accepted that many immunological disorders are involved in Type 1 diabetes, both as humoral immunological signs and as abnormalities in cell-mediated immunity [1]. Now, we suggest that T-lymphocyte subset alterations play an important role. Given that there is a genetically determined defect in suppressor and helper lymphocytes in Type 1 diabetes, it remains to be understood how these non-specific deficits may initiate the wellknown autoaggressive pancreatic damage.

Acknowledgements. The authors wish to thank Professor G. Burgio for statistical analysis, Miss P.D'Acquisto for excellent technical assistance, Miss N.Di Giorgio for typing the manuscript. This work was presented at the $11^{\text {th }}$ International Diabetes Federation Congress, Nairobi, 1982 and was supported in part by a grant from CNR, Italy, N. 82.02102 .56

\section{References}

1. Cahill GF, McDevitt HO (1981) Insulin-dependent diabetes mellitus: the initial lesion. N Engl J Med 304: 1454-1465

2. Buschard K, Madsbad S, Rygaard J (1980) Depressed suppressor cell activity in patients with newly diagnosed insulin-dependent diabetes mellitus. Clin Exp Immunol 41: 25-32

3. Galluzzo A, Giordano C, Sparacino G, Bompiani GD (1980) Studies on suppressor cell function in recent-onset juvenile diabetes. Diabetologia 19: 275 (Abstract)

4. Reinherz EL, Schlossman SF (1980) Current concepts in immunology. Regulation of the immune response-inducer and suppressor T lymphocyte subsets in human beings. N Engl J Med 303: $370-373$

5. Reinherz EL, Kung PC, Breard JM, Goldstein G, Schlossman SF (1980) $\mathrm{T}$ cell requirements for generation of helper function in man: analysis of the subsets involved. J Immunol 124: 1883-1887

6. Reinherz EL, Kung PC, Goldstein G, Schlossman SF (1980) A monoclonal antibody reactive with the human cytotoxic/suppressor $\mathrm{T}$ cell subset previously defined by a heteroantiserum termed $\mathrm{TH}_{2}$. J Immunol 124: 1301-1307

7. Bach MA, Bach JF (1981) The use of monoclonal anti-T cell anti- bodies to study T cell imbalances in human diseases. Clin Exp Immunol 45: 449-456

8. Cudworth AG, Woodrow JC (1976) Genetic susceptibility in diabetes mellitus. Br Med J 2: 846-848

9. Christy M, Green A, Christan B, Kromann H, Nerup J, Platz P, Thomsen M, Ryder L, Svejgaard A (1979) Studies of the HLA system and insulin-dependent diabetes mellitus. Diabetes Care 2: 209-214

10. National Diabetes Data Group (1979) Classification and diagnosis of diabetes mellitus and other categories of glucose intolerance. Diabetes 28: 1039-1057

11. Boyum A (1968) Isolation of mononuclear cells and granulocytes from human blood. Isolation of mononuclear cells by one centrifugation, and of granulocytes by combining centrifugation and sedimentation at $1 \mathrm{~g}$. Scan J Clin Lab Invest 21: (Suppl 97): 77-89

12. Gorer PA, O'Gorman P (1956) The cytotoxic activity of isoantibodies in mice. Transplantation Bull 3: 142-146

13. Bliss CI (1967) In: Statistics in biology, vol 1. McGraw-Hill, New York, pp 186-204

14. Welch BL (1947) Generalization of Student's t problem when several different population variances are involved. Biometrica 34: $28-35$

15. Smolen JS, Chused TM, Leiserson WM, Reeves JP, Alling D, Steimberg AD (1982) Heterogeneity of immunoregulatory T-cell subsets in systemic lupus erythematosus. Am J Med 72: 783-790

16. Maclaren NK, Huang SW (1980) Cell-mediated immunity in insulin-dependent diabetes. In: Irvine WJ (ed) Immunology of diabetes. Teviot Scientific Publications, Edinburgh, pp 185-194

17. Pozzilli P, Zuccarini O, Iavicoli M, Andreani D, Sensi M, Spencer KM, Bottazzo GF, Beverley PCL, Kyner JL, Cudworth AG (1983) Monoclonal antibodies defined abnormalities of $\mathrm{T}$ lymphocytes in Type I (insulin-dependent) diabetes. Diabetes 32: 91-94

18. Jackson RA, Morris MA, Haynes BF, Eisenbarth GS (1982) Increased circulating Ia-antigen-bearing $T$ cells in Type I diabetes mellitus. N Engl J Med 306: 785-788

19. Horita M, Suzuki H, Onodera T, Ginsberg-Fellner F, Fauci AS, Notkins AL (1982) Abnormalities of immunoregulatory $T$ cell subsets in patients with insulin-dependent diabetes mellitus. J Immunol 129: 1426-1429

20. Gepts W, Le Compte PM (1981) The pancreatic islets in diabetes. Am J Med 70: 105-115

21. Kidd A, Okita N, Row VV, Volpé R (1980) The immunologic aspects of Graves' and Hashimoto's diseases. Metabolism 29: $80-84$

22. Kaldany A, Hill T, Wentworth S, Brink SJ, D'Elia JA, Clouse M, Soedner JS (1982) Trapping of peripheral blood lymphocytes in the pancreas of patients with acute-onset insulin-dependent diabetes mellitus. Diabetes 31: 463-466

23. Gorsuch AN, Spencer KM, Lister J, McNally J, Dean BM, Bottazzo GF, Cudworth AG (1981) The natural history of Type I (insulin-dependent) diabetes mellitus: evidence for a long prediabetic period. Lancet 2: 1363-1365

Received: 1 February 1983

and in revised form: 19 March 1984

Dr. Aldo Galluzzo

Clinica Medica III

University of Palermo

Via del Vespro 129

I-90127 Palermo

Italy 